\title{
Effects of COVID-19 on Organizational Psychology in Management and Strategic Context
}

\author{
Fahri Özsungur* \\ Adana Science and Technology University and Mersin University, Turkey \\ *Corresponding author: Fahri Özsungur, Adana Science and Technology University and Mersin University, Turkey
}

\begin{tabular}{|c|c|}
\hline ARTICLE INFO & ABSTRACT \\
\hline & $\begin{array}{l}\text { This study aims to identify the differences of businesses born in the period of } \\
\text { COVID-19 from other companies operating in similar sectors in terms of organizational }\end{array}$ \\
\hline Published: 㓞 March 26, 2021 & \\
\hline $\begin{array}{l}\text { Citation: Fahri Özsungur. Effects of } \\
\text { COVID-19 on Organizational Psychology } \\
\text { in Management and Strategic Context. } \\
\text { Biomed J Sci \& Tech Res 34(5)-2021. } \\
\text { BJSTR. MS.ID.005608. }\end{array}$ & $\begin{array}{l}\text { of the restaurant, cafe, retail, and virtual store established before March } 2020 \text { in } \\
\text { Turkey, when the first cases of the COVID-19 emerge, and the businesses born after } \\
\text { the pandemic operating in Adana in these sectors. According to the findings of the } \\
\text { study, three basic dimensions that highlight organizational psychology in coding were } \\
\text { determined: Internalization and perception in psychology, psychology management, } \\
\text { reactivity. According to the findings obtained from the participants, the management } \\
\text { factors affecting the organizational psychology of the enterprises established before the } \\
\text { COVID-19 period were determined as employee and human resources management, } \\
\text { innovation and entrepreneurship, intra-organizational and corporate compliance. }\end{array}$ \\
\hline
\end{tabular}

\section{Introduction}

COVID-19 continues to reveal the most common harmful effects of today's world. These effects give a negative momentum to the psychology of individuals [1]. Among these effects is the inability of elderly people to leave their homes and the inability of children and young people to live freely. Urban life offers a limited living space under the influence of the pandemic [2]. Developing technology and digital possibilities are not enough to reduce the impact of the pandemic [3]. Despite the fact that daily vital activities are limited in the light of these developments, inter-human interaction continues at a minimal level in order to meet biological needs. While this situation slows down the effects of the pandemic, it cannot prevent mutation [4]. Human behavior and psychology have important consequences under the oppressive, social isolation effect of the pandemic [5]. One of these results is organizational psychology. Organizational psychology is the behavioral patterns and direction of organizational functions that mimic human psychology [6]. Due to the nature of human psychology, its differentiation according to time and conditions affects organizational functions and behaviors. Managerially, the decisions of leaders in the same direction with their psychology affect the functional outputs of the organization. The fact that the pandemic period creates extraordinary situations affects organizational psychology in terms of administration, so that inter-organizational and social conflicts can be experienced. In this context, this study reveals the differences of businesses born in the period of COVID-19 from other companies operating in similar sectors in terms of organizational psychology. In addition, the study aims to determine the basic dimensions of organizational psychology and the factors of these dimensions.

\section{Methodology}

\section{Sample}

The study was conducted with a total of 48 businesses of the restaurant, cafe, retail, and virtual store established before March 2020 in Turkey, when the first cases of the COVID-19 emerge, and the businesses born after the pandemic operating in Adana in these sectors. The study was applied in January 2021. Human resources, manufacturing and planning, after-sales services, and executive personnel of each business were included in the study. 


\section{Data Collection and Analysis}

One of the qualitative research methods, the phenomenology method was adopted in the study [7]. After the research questions were determined, a face-to-face interview was conducted with the participants included in the study. Participants were informed that participation was voluntary and that they could end answering research questions at any time. The research questions applied to the participants are specified in Table 1 . The questions in Table 1 were obtained as a result of an extensive literature review. After the dimensions and subdimensions were obtained, the questions were directed according to the contents in the table. The questions asked

Table 1: Research questions. to differ according to the sector, organizational structure, turnover, and employee characteristics of each enterprise. Therefore, the unstructured interview technique was applied in the study [8]. The obtained data were recorded with traditional methods and an indepth investigation of experiences and knowledge in organizational psychology was carried out through interpretive phenomenology [9]. Field description, classification, and component analysis were applied respectively in data analysis. Categories were created by coding the data [10-18]. Thus, the subject titles and contents obtained by the classification were subjected to validity and reliability analysis [19].

\begin{tabular}{|c|c|}
\hline Order & Questions \\
\hline 1 & What are the main factors affecting the psychological behavior of employees and businesses? \\
\hline 2 & $\begin{array}{c}\text { When you think of your business as a human, what are the factors that affect the development of its relations with the external } \\
\text { environment? }\end{array}$ \\
\hline 3 & Could you give information about the well-being of the employees in the workplace and within the business? \\
\hline 4 & $\begin{array}{c}\text { Could you give information about the relationship between the performance of your business, teamwork, and the commitment of } \\
\text { employees to the business? }\end{array}$ \\
\hline 5 & Could you give information about your human resources policy? \\
\hline 7 & Can you tell us the words that come to mind when you talk about organizational psychology? \\
\hline 8 & Can you tell us the words that come to mind when you talk about business psychology? \\
\hline 9 & What do you think are the main differences between the concept of organizational psychology and human psychology? \\
\hline 10 &
\end{tabular}

\section{Results}

\section{Demographic Characteristics}

Demographic findings are shown in Table 2. According to the research findings, $39.79 \%$ of the participants were women and
$60.21 \%$ were men. $85.72 \%$ of the participants were between the ages of 19-40. In addition, when the demographics of the participants were examined, the restaurant was $22.91 \%$, cafe $25.00 \%$, retail $20.83 \%$, and virtual store $58.74 \%$.

Table 2: Demographic information of the sample included in the study.

\begin{tabular}{|c|c|c|c|c|c|c|c|}
\hline & & \multicolumn{2}{|c|}{ Before COVID-19 (March 2020) } & \multicolumn{2}{|c|}{ After COVID-19 (March 2020) } & \multicolumn{2}{|c|}{ Total } \\
\hline & & f & $\%$ & f & $\%$ & f & $\%$ \\
\hline \multirow[t]{2}{*}{ Gender } & Women & 24 & 46,15 & 15 & 32.61 & 39 & 39.79 \\
\hline & Men & 28 & 53.85 & 31 & 67.39 & 59 & 60.21 \\
\hline \multirow[t]{3}{*}{ Age } & $19-29$ & 19 & 36.53 & 21 & 45.65 & 40 & 40.82 \\
\hline & $30-40$ & 21 & 40.39 & 23 & 50.00 & 44 & 44.90 \\
\hline & 41 and over & 12 & 23.08 & 2 & 4.35 & 14 & 14.28 \\
\hline \multirow[t]{4}{*}{ Sector (Service) } & Restaurant & 7 & 27.92 & 4 & 18.18 & 11 & 22.91 \\
\hline & Cafe & 8 & 30.76 & 4 & 18.18 & 12 & 25.00 \\
\hline & Retail & 5 & 19.23 & 5 & 22.72 & 10 & 20.83 \\
\hline & Virtual Store & 6 & 22.09 & 9 & 40.92 & 15 & 58.74 \\
\hline
\end{tabular}

\section{Qualitative Findings}

Findings Regarding the Functions and Dimensions of Organizational Psychology: According to the findings of the study, three basic dimensions that highlight organizational psychology in coding were determined: Internalization and perception in psychology, psychology management, reactivity. Internalization and perception in psychology, which are among these basic dimensions, were revealed as a result of coding two sub-dimensions: job analysis, organizational culture. In the answers given to the questions, it 
was emphasized that the most important factor in the emergence of organizational psychology was employee and job descriptions. Employees' knowledge, skills, and adaptation to the workplace were stated as important for the organizational reflections of individual psychology. On the other hand, the organizational culture that emerges with the employees' ties and relationships with the workplace, job, leader, manager, was revealed as another critical factor by the participants. Especially, the total values adopted within the organization, ethics, and communication that stand out in the organization-employee relationship, create the organizational culture and trigger the psychological perception of the organization Table 3. The second basic dimension of organizational psychology mentioned by the participants was psychology management.
Psychology management reveals three basic functions: Leadership and management, Group Behavior, and Performance Management. Participants believe that leadership and management are an important driving force in the management of organizational psychology. Therefore, the energy resulting from the interactions between managers and leaders, and employees create a synergy in the context of organizational psychology. Besides, according to the participants, the emergence of organizational psychology as a result of group behavior is an important indicator in relation to the external environment. For this reason, issues such as project management, teamwork, fair distribution of tasks, teamwork are of key importance in the management of this psychology.

Table 3: Content and size of research questions.

\begin{tabular}{|c|c|c|}
\hline Dimensions & Subdimensions & Content \\
\hline \multirow{2}{*}{$\begin{array}{c}\text { Internalization and } \\
\text { perception in psychology }\end{array}$} & Job Analysis & Duties, tasks, knowledge, skills, competencies, compatibility, job-relevant selection \\
\cline { 2 - 3 } Psychology Management & Leadership and management & Communication, ethics, values, acceptance/adoption behaviour \\
\cline { 2 - 3 } & Froup behavior & $\begin{array}{c}\text { Team effectiveness, Team composition, Task design, Organizational resources, Team } \\
\text { rewards, Team goals }\end{array}$ \\
\cline { 2 - 3 } & Performance Management & $\begin{array}{c}\text { Occupational health and well-being, workplace bullying, boreout-boredom, } \\
\text { stress-depression-anxiety, mobing, aggression and violence, remuneration and } \\
\text { compensation, training, motivation in the workplace, occupational safety }\end{array}$ \\
\hline Reactivity & Organizational psychology outputs & $\begin{array}{c}\text { Job satisfaction and commitment, Productive behavior, Job performance, } \\
\text { Organizational citizenship behavior, Innovation, entrepreneurship, rivalry power }\end{array}$ \\
\hline
\end{tabular}

Psychology management requires the management of the total performance of the organization in relation to the external and internal environment. The effects of positive psychology are necessary for controlling the psychological conditions of the employees. Participants stated that performance in organizational psychology depends on the elimination of negative psychological states. It was emphasized by the participants that negative states such as mobbing, workplace bullying, boreout-boredom, stressdepression-anxiety, aggression, and violence would have negative reflections on organizational psychology. The positive psychological state was less emphasized by the participants than the negative state. It was emphasized that the organizational/business climate was important for the team and group work outcomes of the employees to contribute to the organizational psychology as a performance output. It was emphasized that periodic/sustainable training on the negative psychological states should be given to managers and employees on these issues. In organizational psychology, after the internalization (perceptual) and managerial processes of organizational psychology, findings revealed the dimension of reactivity. Participants explained that organizational psychology was related to job satisfaction and commitment, productive behavior, job performance, organizational citizenship behavior, innovation, entrepreneurship, and rivalry power. The participants stated that the innovative and entrepreneurial behavior of the organization was a psychological reaction, and this response was necessary for the sustainability of the organization. It was found that concepts such as commitment, adoption, dependency, and satisfaction came to the fore in the coding of the contents of the findings obtained in revealing this dimension.

Findings on the Effects of COVID-19: In order to reveal the effects of COVID-19 on organizational psychology in management and strategic context, the following questions were asked: What are the main factors affecting the psychological behavior of employees and businesses? When you think of your business as a human, what are the factors that affect the development of its relations with the external environment? Could you give information about the well-being of the employees in the workplace and within the business? Which factors do you think are the most influential in your business's innovative, entrepreneurial, competitive, or aggressive behavior? Could you give information about the relationship between the performance of your business, teamwork, and the commitment of employees to the business? Could you give information about your human resources policy? What effect did COVID-19 have on the performance, management, employee, productivity, organizational structure, and all other aspects of your business? According to the findings obtained from the participants, the management factors affecting the organizational psychology of the enterprises established before the COVID-19 period were 
determined as employee and human resources management, innovation and entrepreneurship, intra-organizational and corporate compliance. In addition, the strategic factors that affect the organizational psychology of the enterprises started up in this period are management strategy, leadership, and corporate strategy Table 4.

Table 4: Effects of COVID-19 on organizational psychology in management and strategic context.

\begin{tabular}{|c|c|c|c|c|c|c|}
\hline \multirow{2}{*}{$\begin{array}{c}\begin{array}{c}\text { Organizational } \\
\text { Psychology }\end{array} \\
\text { Businesses Born } \\
\text { After Covid-19 } \\
\text { (March 2020) }\end{array}$} & \multicolumn{3}{|c|}{ Businesses Born Before Covid-19 (March 2020) } & \multicolumn{3}{|c|}{ Businesses Born After Covid-19 (March 2020) } \\
\hline & Factors & $\mathbf{n}$ & $\%$ & Factors & $\mathbf{n}$ & $\%$ \\
\hline \multirow{3}{*}{ Management } & $\begin{array}{l}\text { Employee and Human } \\
\text { Resources Management }\end{array}$ & 33 & 42.85 & Customer Management & 39 & 33.62 \\
\hline & $\begin{array}{l}\text { Innovation and } \\
\text { entrepreneurship }\end{array}$ & 23 & 29.87 & $\begin{array}{l}\text { Innovation and } \\
\text { entrepreneurship }\end{array}$ & 34 & 29.31 \\
\hline & $\begin{array}{l}\text { Intra-organizational and } \\
\text { corporate compliance }\end{array}$ & 21 & 27.28 & Crisis management & 43 & 37.07 \\
\hline \multirow{3}{*}{ Strategy } & Management strategy & 34 & 34.69 & Management strategy & 31 & 32.63 \\
\hline & Leadership & 33 & 33.67 & Leadership & 22 & 23.16 \\
\hline & Corporate strategy & 31 & 31.64 & $\begin{array}{c}\text { Competitive and Financial } \\
\text { Strategy }\end{array}$ & 42 & 44.21 \\
\hline
\end{tabular}

The management factors that affect the organizational psychology of businesses born in the COVID-19 period are customer management, innovation and entrepreneurship, and crisis management. On the other hand, the strategic factors that affect the organizational psychology of the enterprises established in this period are management strategy, leadership, and competitive and financial strategy. When the data for both periods are compared, it can be said that COVID-19 pushed businesses to adopt a strategy based on protecting their financial resources and customers. Before COVID-19, businesses had a tendency towards institutionalization, but after the pandemic, this situation changed to preserve the current competition and financial status.

\section{Discussion and Conclusion}

The findings of the study reveal the existence of three dimensions of organizational psychology based on perception, management, and reactivity. These findings have not been determined before in the literature. In the literature, organizational psychology has been the subject of research on group performance, productivity, job-related attitudes, culture, organizational identification, group norms, jobrelated behaviors [20-26]. However, these studies generally focus on the commitment of the employee to the workplace and job, performance, and group behaviors. The results obtained from this research measure the behavioral differences between businesses before the COVID-19 period and those established in the postCOVID-19 period in the context of organizational psychology. The findings of the study show the importance given to customer and crisis management in organizational psychology in the context of management due to the effect of COVID-19. On the other hand, in a strategic context, organizational psychology highlights the competition and financial strategies of businesses born in the period of COVID-19. This situation clearly shows the effects of the pandemic on the psychological behavior of employees, groups, and businesses.

In practice, businesses that are trying to develop corporate strategies practically have had to change their strategies with the effect of the pandemic. This development has changed the psychological behavior and tendencies of the organization. The importance of managerial elements such as innovation and entrepreneurship increase even more in extraordinary situations. Therefore, digital elements are indispensable infrastructure elements in the production and service sectors. These infrastructural elements are necessary for improving organizational psychology. The study is limited to restaurant, café, retail, and virtual store businesses operating in Adana Turkey. Therefore, the sample limitation of the study affects the generalizability of the results. It is recommended that the study be carried out in different sectors and regions. In addition, future research on enterprises operating in the manufacturing sector on the subject of study will contribute to the organizational psychology literature.

\section{References}

1. Adhabi E, Anozie CB (2017) Literature review for the type of interview in qualitative research. International Journal of Education 9(3): 86-97.

2. Arden M A, Chilcot J (2020) Health psychology and the coronavirus (COVID-19) global pandemic: A call for research. British journal of health psychology 25(2): 231-232.

3. Bal PM, Dóci E (2018) Neoliberal ideology in work and organizational psychology. European Journal of Work and Organizational Psychology 27(5): 536-548.

4. Berry LM, Houston JP (1993) Psychology at work: An introduction to industrial and organizational psychology. Brown \& Benchmark/Wm. C. Brown Publ. 
5. Campbell J P (1990) Modeling the performance prediction problem in industrial and organizational psychology. In M. D. Dunnette \& L. M. Hough (Eds.), Handbook of industrial and organizational psychology (p. 687-732). Consulting Psychologists Press.

6. Cascio W F, Aguinis H (2008) Research in industrial and organizational psychology from 1963 to 2007: Changes, choices, and trends. Journal of Applied Psychology 93(5): 1062-1081.

7. Christensen M, Welch A, Barr J (2017) Husserlian Descriptive Phenomenology: A review of intentionality, reduction and the natural attitude. Journal of Nursing Education and Practice 7(8): 113-118.

8. Cvitanovic C, Colvin RM, Reynolds KJ, Platow MJ (2020) Applying an organizational psychology model for developing shared goals in interdisciplinary research teams. One Earth 2(1): 75-83.

9. Drenth PJ, Thierry H, Wolff CJ (2001) Organizational psychology (Vol. 4). Psychology Press.

10. Spector PE (2006) Industrial and organizational psychology: Research and practice. John Wiley \& Sons Inc.

11. Esterberg KG (2002) Qualitative Methods. Social Research. Boston, MA. Mcgraw Hill.

12. Grubaugh ND, Hanage WP, Rasmussen AL (2020) Making sense of mutation: what D614G means for the COVID-19 pandemic remains unclear. Cell 182(4): 794-795.

13. Guan Y, Deng H, Zhou X (2020) Understanding the impact of the COVID-19 pandemic on career development: Insights from cultural psychology 119.

14. Huberman M, Miles MB (2002) The qualitative researcher's companion. Sage.

15. Hwang TJ, Rabheru K, Peisah C, Reichman W, Ikeda M, et al. (2020) Loneliness and social isolation during the COVID-19 pandemic. International Psychogeriatrics 32(10): 1217-1220.

\section{ISSN: 2574-1241}

DOI: 10.26717/BJSTR.2021.34.005608

Fahri Özsungur. Biomed J Sci \& Tech Res

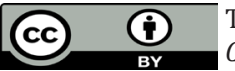

This work is licensed under Creative Commons Attribution 4.0 License

Submission Link: https://biomedres.us/submit-manuscript.php
16. Jetten J (2020) Together apart: The psychology of COVID-19. Sage.

17. Miles MB, Huberman AM, Saldaña J (2018) Qualitative data analysis: A methods sourcebook. Sage publications.

18. Muchinsky PM (2000) Psychology applied to work: An introduction to industrial and organizational psychology. Wadsworth/Thomson Learning.

19. Patton MQ (1987) How to use qualitative methods in evaluation (No. 4). Sage.

20. Peçanha T, Goessler KF, Roschel H, Gualano B (2020) Social isolation during the COVID-19 pandemic can increase physical inactivity and the global burden of cardiovascular disease. American Journal of PhysiologyHeart and Circulatory Physiology 318(6): H1441-H1446.

21. Qutoshi SB (2018) Phenomenology: A philosophy and method of inquiry. Journal of Education and Educational Development 5(1): 215-222.

22. Schultz DP, Schultz SE (1986) Psychology and industry today: An introduction to industrial and organizational psychology. Macmillan Publishing Co, Inc.

23. Seale C (2001) Qualitative methods: Validity and reliability. European Journal of Cancer Care 10(2): 133-134.

24. Seaman CB (2008) Qualitative methods. In Guide to advanced empirical software engineering (pp. 35-62). Springer, London.

25. Whitelaw S, Mamas MA, Topol E, Van Spall HG (2020) Applications of digital technology in COVID-19 pandemic planning and response. The Lancet Digital Health 8(2): E435-E440.

26. Van Dick R (2001) Identification in organizational contexts: Linking theory and research from social and organizational psychology. International Journal of Management Reviews 3(4): 265-283.

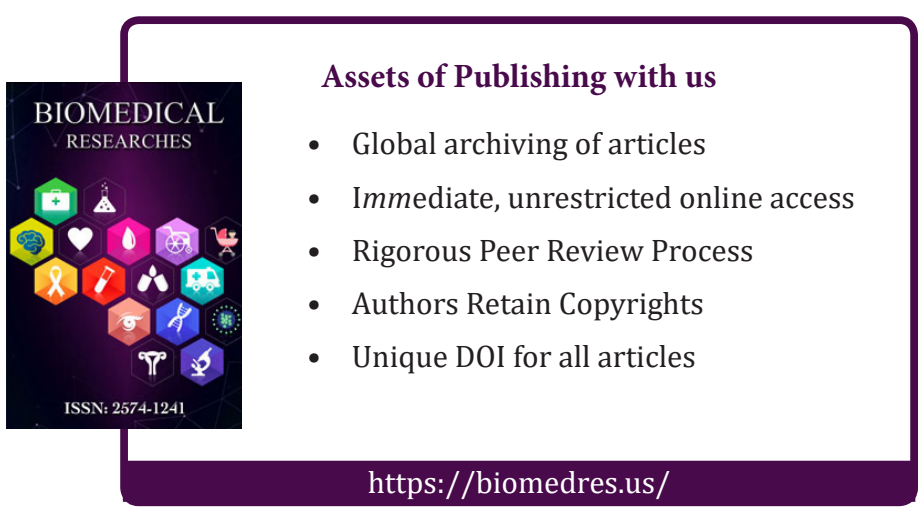

